\title{
Monitoring of water quality in the basin of São João river and detection of agrochemical glyphosate in the water reservoir for urban supply in the municipality of Porto Nacional, Tocantins, Brazil
}

In this work we used the Water Quality Index (WOI) aiming to evaluate the water quality and to detect glyphosate agrotoxic concentrations In the catchment reservoir for urban supply of the São João Creek, in Porto Nacional, in the state of Tocantins, the only one source of supply which has been suffering several attacks, such as agricultural and cattle raising's exploitation, where various catchments for irrigation are situated. This study was carried out monitoring of water of the São João creek, this water resource very importance for the city of Porto Nacional - TO, which has applications in multiple uses such as fishing, leasure of primary contact, water supply, landscape harmony, among others. The parameters analyzed in this work are: temperature, oxygen, $\mathrm{pH}$, total nitrogen, total phosphorus, total coliforms, total solids and turbidity in the months from august 2017 to september 2018 employed in calculating the quality index National Sanitation Foundation (IQA-NSF) and glyphosate agrotoxic concentrations in sediment from the catchment reservoir for urban supply in the same period. The results showed that the water São João Creek can be classified as medium quality with an average of 69,10 seconds NSF, although some parameters compared with environmental laws were not in accordance with the standards determined by Resolutions 274/2000 and 357/2005 of the Brasilian National Council of Environment (CONAMA). On the other hand, concentrations of glyphosate agrotoxic did not exceed the limit allowed by CONAMA Resolution 357/2005, which obtained an average of approximately $0.05 \mu \mathrm{g} / \mathrm{L}$ for the study period, but it should be noted that in the rainy season it reached values of $0,9 \mu \mathrm{g} / \mathrm{L}$, that is, values close to the permissible limit of the European Union, indicating, thus, the accumulation in the long term.

Keywords: IQA; Glyphosate; Watershed.

\section{Monitoramento da qualidade da água na bacia do rio São João e deteç̧ão de glifosato agroquímico em reservatório de água para abastecimento urbano no município de porto nacional, Tocantins, Brasil}

\begin{abstract}
Neste trabalho utilizou-se o Índice de Qualidade de Água (IQA) com o objetivo de avaliar a qualidade da água e detectar as concentrações do agrotóxico glifosato no reservatório de captação para abastecimento urbano do Ribeirão São João, em Porto Nacional, no Estado do Tocantins, principal fonte de abastecimento, que vem sofrendo inúmeras agressões, como, exploração da agricultura e pecuária, onde se localizam diversas captações para irrigação. Neste estudo foi realizado um acompanhamento da qualidade das águas do Ribeirão São João, recurso hídrico de grande importância para o município, que tem aplicação em usos múltiplos como: pesca, lazer de contato primário, abastecimento, harmonia paisagística, dentre outros. Os parâmetros analisados foram temperatura, oxigênio, $\mathrm{pH}$, nitrogênio total, fósforo total, coliformes totais, sólidos totais e turbidez, no período amostral de agosto de 2017 a setembro de 2018 empregados no cálculo do índice de qualidade da National Sanitation Foundation (IQA-NSF) e as concentrações do agrotóxico glifosato nos sedimentos do reservatório de captação para abastecimento urbano no mesmo período. Os resultados obtidos demonstraram que a água do Ribeirão São João pode ser classificada como de qualidade mediana com média de 69,10 segundo a NSF, urbano no mesmo período. Os resultados obtidos demonstraram que a água do Ribeirão São João pode ser classificada como de qualidade mediana com média de 69,10 segundo a NSF, embora alguns parâmetros comparados com a legislação ambiental ficaram em desacordo com os padrões determinados pela Resolução $357 / 2005$ do Conselho Nacional do Meio Ambiente uma média de aproximadamente de $0,05 \mu \mathrm{g} / \mathrm{L}$ para o período em estudo, mas vale ressaltar que no período chuvoso chegou a valores de 0,09 $\mu \mathrm{g} / \mathrm{L}$, ou seja, valores próximos ao limite permissível da União Européia, indicando assim, a acumulação a longo prazo.
\end{abstract}

Palavras-chave: IQA; Glifosato; Bacia Hidrográfica.

Topic: Uso Sustentável da Biodiversidade

Reviewed anonymously in the process of blind peer.

Angelo Ricardo Balduino (iD)

Universidade Federal do Tocantins, Brasil http://lattes.cnpq.br/8475669590774317 http://orcid.org/0000-0002-7082-2566

angelo.balduino@uft.edu.br

Deusiano Florêncio dos Reis

Universidade Federal do Tocantins, Brasil http://lattes.cnpq.br/1018309854747533

http://orcid.org/0000-0003-1801-1640

deusiano@uft.edu.br

Albano Dias Pereira Filho (iD

Instituto Federal do Tocantins, Brasil

http://lattes.cnpq.br/3210452932144387

http://orcid.org/0000-0002-6515-6335

albano.filho@ifto.edu.br

DOI: 10.6008/CBPC2179-6858.2019.002.0009

Received: $12 / 02 / 2019$

Approved: 28/03/2019

\author{
Lucas Barbosa Souza (iD \\ Universidade Federal do Tocantins, Brasil \\ http://lattes.cnpq.br/8310303536103062 \\ http://orcid.org/0000-0001-7957-088X \\ lbsgeo@uft.edu.br \\ Marcio Galdino dos Santos \\ Universidade Federal do Tocantins, Brasil \\ http://lattes.cnpq.br/0838790668957109 \\ http://orcid.org/0000-0002-2570-9425 \\ galdino@uft.edu.br
}

Referencing this:

BALDUINO, A. R.; REIS, D. F.; PEREIRA FILHO, A. D.; SOUZA, L. B.; SANTOS, M. G.. Monitoring of water quality in the basin of são joão river and detection of agrochemical glyphosate in the water reservoir for urban supply in the municipality of porto nacional/Tocantins, Brazil. Revista Ibero Americana de Ciências Ambientais, v.10, n.2, p.83-108, 2019. DOI: http://doi.org/10.6008/CBPC2179-

$\underline{6858.2019 .002 .0009}$ 


\section{INTRODUCTION}

Water is one of the main natural resources for the society, being indispensable for our survival. Approximately one billion people, or one in seven people in the world, do not have access to fresh drinking water. A large part of the world's population does not have access to basic sanitation services and about $20 \%$ of the world's hydric systems, which maintain the sustainable development of ecosystems and feed a large part of the human population, are under water scarcity conditions. Rivers, lakes and aquifers are reducing their volume and becoming too polluted for consumption (JACOBI, 2015).

Several authors state that the problems related to water quality are the result of the inadequate provisions of solid and liquid waste, whether of industrial or domestic origin, changes caused by agricultural practices, livestock and developments for the generation of energy, all of which having major impacts on the natural processes in the river basins. According to Bohner (2011), agricultural practices and the natural vulnerability of the aquifer may represent a high level of negative impacts, thus rendering water unfit for consumption.

The environmental index and indicators were stablished as a result of the growing concern with the social aspects of human development, a process that requires a greater number of information, in a complexity degree. On the other hand, indicators have become fundamental in the decision-making processes of public policies and in the monitoring of their effects (SPERLING, 2005). The monitoring of the quality of a river basin area through sampling process has the goal of obtaining quantitative and qualitative information, with specific purposes, such as the physical-chemical, biological and ecological conditions, besides framing any given body of water in classes or for inspection and control effects.

The pollutants reach the water through precipitation, infiltration, drainage, erosion, among other forms. According to Carneiro et al. the data collected by the National Agency of Health Surveillance (ANVISA) and Agrochemical Industry Observatory of the Federal University of Paraná (UFPR), released during the II Seminar on Agrochemicals and Regulation Market, held in Brasilia, Federal District, in April 2012, stated that, while in the last 10 years the world market for agrochemicals grew 93\%, the Brazilian market grew $190 \%$.

The correlation between water quality and sanitation is pretty close, because it has the function of promoting a better quality of life for the population. Anthropogenic activities associated with industrialization and agriculture have contributed greatly to the deterioration of the quality of both surface and groundwater used for public supply, resulting in a risk for human health and aquatic ecosystems (MUDIAM et al., 2012). In view of this reality, this study determined the water quality in the São João River basin through the Water Quality Index (IQA-NSF), and to detect concentrations of glyphosate agrochemical in the water reservoir for urban supply, in the municipality of Porto Nacional, State of Tocantins, from August 2017 to September 2018, and verifying if they meet the standards established by Resolutions 357/2005 of the National Environmental Council (CONAMA). 
Monitoring of water quality in the basin of São João river and detection of agrochemical glyphosate in the water reservoir for urban supply in the

\section{METHODS}

\section{Study Area}

The study was performed in the São João River basin, which has a drainage area of approximately $81.97 \mathrm{~km}^{2}$, presenting seven drainage channels with a total length of $35.5 \mathrm{~km}$, with a length of $15.75 \mathrm{~km}$ as its main channel, basin length of $22 \mathrm{~km}$, and with the watershed representing a perimeter of $46.26 \mathrm{~km}$ and an altimetric range of 323 meters (OLIVEIRA et al., 2014). It is located in the municipality of Porto Nacional (Figure 1), with an area of $4,464.11 \mathrm{~km}^{2}$, corresponding to $1.61 \%$ of the total area of the state of Tocantins, and with an estimated population of 52,510 inhabitants (IBGE, 2018) and in a distance of $62 \mathrm{~km}$ from the capital Palmas.
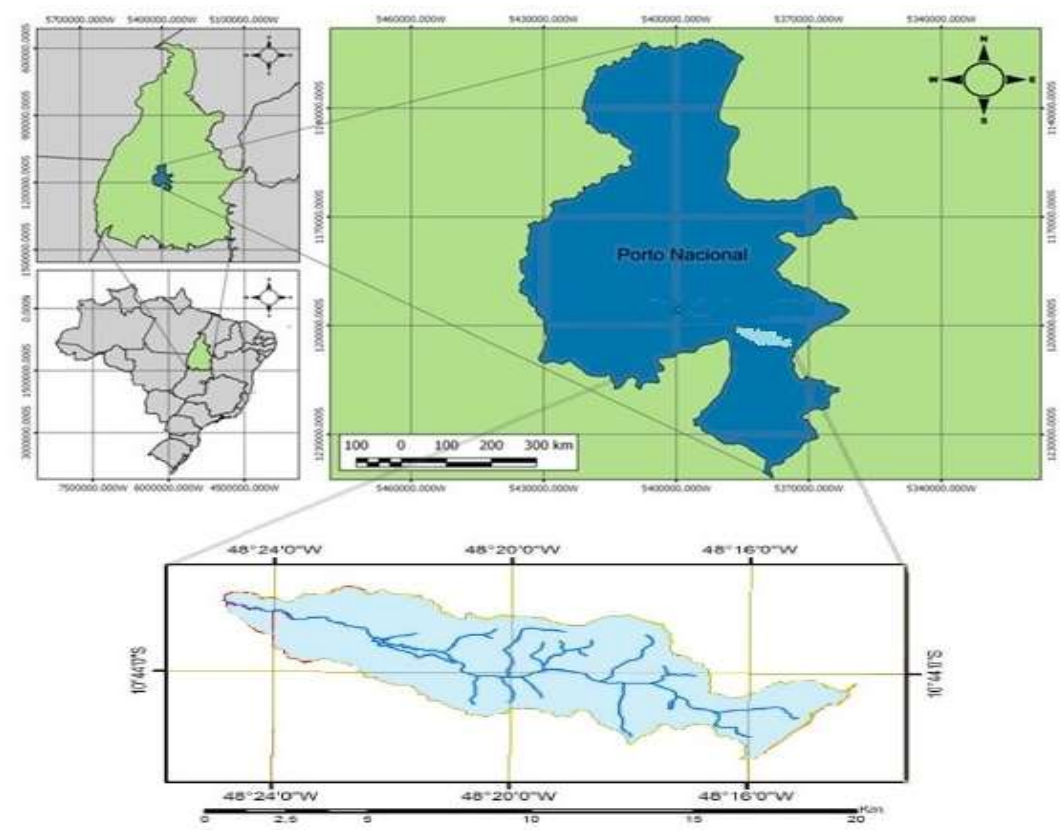

Figure 1: River Basin of the São João River in the municipality of Porto Nacional/Tocantins.

According to Balduino et al. (2018), the climate of Porto Nacional is Sub-humid, with two well-defined seasons, rainy and dry, with the dry happening in the winter season in which it presents moderate and megahermic water deficiency, with high annual values of potential evapotranspiration, with $28.29 \%$ of this evapotranspiration concentrated in the summer season, and can be defined by the formula C2 $\mathrm{wA}^{\prime} \mathrm{a}$ ', and in the last 20 years of analysis, the annual average precipitation and temperature were, respectively, $1563 \mathrm{~mm}$ and $27,28^{\circ} \mathrm{C}$. The dominant natural vegetation in the basin area corresponds to the savanna.

The samples were collected at three main points (PI, PII and PIII), according to Table 1, distributed along the water body, according to Figure 2, during fourteen months, from August 2017 to September 2018, with the first months of August to September 2017, June to September 2018, which corresponded to the dry season, and from October 2017 to May 2018, which corresponded to the rainy season. For the selection of water collecting points in the São João River basin, it were performed bibliographic studies related to the area and field visits to obtain information that could help the definition of collecting points and possible causes of water contamination. 
Monitoring of water quality in the basin of São João river and detection of agrochemical glyphosate in the water reservoir for urban supply in the

Table 1: Location of the points of water collection of the São João River in Porto Nacional, Tocantins, in the months of August 2017 to September 2018.

\begin{tabular}{|l|l|l|l|}
\hline Point (P) & Latitude (S) & Longitude (W) & Place of Reference \\
\hline I & $10^{\circ} 44^{\prime} 16,34^{\prime \prime}$ & $48^{\circ} 17^{\prime} 38,17^{\prime \prime}$ & Source (Pilão Farm); \\
\hline II & $10^{\circ} 44^{\prime} 14,22^{\prime \prime}$ & $48^{\circ} 20^{\prime} 15,37^{\prime \prime}$ & Quilombola Community; \\
\hline III & $10^{\circ} 43^{\prime} 04,52^{\prime \prime}$ & $4^{\circ} 22^{\prime} 19,77^{\prime \prime}$ & Water reservoir of urban supply \\
\hline
\end{tabular}

\section{Analysis of quality parameters of the water samples}

In order to perform the study in the São João river basin, three water sampling points were established, and the collection, transport and analysis of the samples were followed by the Standard Methods methodologies (APHA, 2005). The water quality parameters evaluated in this work were: temperature, dissolved oxygen, biochemical oxygen demand, $\mathrm{pH}$, total nitrogen, total phosphorus, turbidity, total coliform, total solids and glyphosate agrochemical concentration in the sediment.

It were analyzed 42 water samples for microbiological and physicochemical parameters and 14 sediment samples from the urban supply reservoir (capture dam), which were collected on fourteen occasions from August 2017 to September 2018, and in each sampling of the three points, the samples were collected and sent to the laboratory on the same day, in an period of approximately 30 days (monthly), with eight months in the rainy season, and six months in the dry season.

\section{Field Methodology}

The field samples were taken with a river collector according to the NBR-9897, in a superficial manner, with a depth of approximately $20 \mathrm{~cm}$, collecting one liter of water, and for the analysis of the concentration of the agrochemical glyphosate it was collected the background sediment in the water reservoir, which were performed using the Pertesen type sampler, and in situ measurements were performed with portable devices specific to each parameter. The temperature of the water and the dissolved oxygen were determined in locu with oximeter model SL 520, according to the protocol of the apparatus.

\section{Laboratory Methodology}

The samples were collected in specific bottles for each parameter, packed in thermal boxes containing ice and sent to the Laboratory of Chemistry/Limnology of the Federal Institute of Education, Science and Technology of Tocantins (IFTO), Porto Nacional, Tocantins campus. Fecal coliforms (CF) were analyzed by the Colilert technique; Total nitrogen was analyzed by the micro Kjeldahl method; Total Phosphorus through the ascorbic acid method after digestion with ammonium persulfate; Biochemical Oxygen Demand (BOD) were determined by standard method A; Total Solids were analyzed by the porcelain capsule method; Glyphosate was detected by GC/MS (gas chromatograph with mass detector) using capillary columns containing several stationary phases and the use of selective detectors; according to the methodologies described in Table 2, established by the Standard Methods for the Examination of Water and Wastewater (APHA, 2005). 
Monitoring of water quality in the basin of São João river and detection of agrochemical glyphosate in the water reservoir for urban supply in the municipality of Porto Nacional, Tocantins, Brazil

Table 2: Parameters and Techniques Used.

\begin{tabular}{|l|l|l|}
\hline Parameters & Analytical Technique & Unit \\
\hline Turbidity & APHA (2005), Direct Measurement & NTU \\
\hline pH & APHA (2005), Direct Measurement & Scale \\
\hline DBO & APHA (2005), Differentiation & $\mathrm{mg} / \mathrm{L}$ \\
\hline Total Phosphorus & APHA (2005), Differentiation & $\mathrm{mg} / \mathrm{L}$ \\
\hline Total Waste & APHA (2005), Evaporation & $\mathrm{mg} / \mathrm{L}$ \\
\hline Total Nitrogen & APHA (2005), Differentiation & $\mathrm{mg} / \mathrm{L}$ \\
\hline Fecal Coliforms & APHA (2005), Colilert & $\mathrm{NMP} / 100 \mathrm{ml}$ \\
\hline Glyphosate & APHA (2005), Detection & $\mu \mathrm{g} / \mathrm{L}$ \\
\hline
\end{tabular}

\section{Calculation of the Water Quality Index (IQA)}

The IQA was calculated by the multiplicative weighted mathematical form of the water quality corresponding to the parameters: sample temperature, $\mathrm{pH}$, dissolved oxygen saturation percentage, biochemical oxygen demand $\left(5\right.$ days, $20^{\circ} \mathrm{C}$ ), fecal coliforms, total nitrogen, phosphorus total solids and turbidity. Being exposed by the equation:

$$
I Q A=\prod_{i=1}^{n} q_{i}^{w i} \quad \text { (Equation 1) }
$$

Where:

IQA: Water Quality Index, a number between 0 and 100; qi: quality of the ith parameter, a number between 0 and 100, obtained from the respective average curve of quality variation for each parameter, depending on its concentration or measurement; wi: weight corresponding to the i-th parameter or sub-level, a number between 0 and 1 (Table 3), attributed as a function of its importance to the overall conformation of quality, where:

$$
\sum_{i=1}^{n} W i=1 \quad \text { (Equation 2) }
$$

In which: $\mathrm{n}$ : number of parameters that are part of the IQA calculation

\begin{tabular}{|c|c|}
\hline PARAMETERS & WEIGHT (WI) \\
\hline Dissolved (OD) & 0,17 \\
\hline Thermotolerant Coliforms (CTe) & 0,16 \\
\hline Potential Hydrogenion $(\mathrm{pH})$ & 0,11 \\
\hline Biochemical Oxygen Demand (BOD) & 0,11 \\
\hline Nitrates $\left(\mathrm{NO}_{3}\right)$ & 0,10 \\
\hline Phosphates $\left(\mathrm{PO}_{4}\right)$ & 0,10 \\
\hline Temperature $(\mathrm{T})$ & 0,10 \\
\hline Turbity (Turb) & 0,08 \\
\hline Total Dissolved Solids (STDs) & 0,07 \\
\hline$\Sigma$ & 1,0 \\
\hline
\end{tabular}

Table 3: Parameters and weights for the calculation of IQA - NSF.

Fonte: Yisa et al. (2012).

The water quality classification for the river water was performed according to the levels specified in Table 4.

Table 4: Quality level or water classification according to IQA-NSF result.

\begin{tabular}{|l|l|}
\hline Quality Level & Range \\
\hline Excellent & $90<$ IQA $\leq 100$ \\
\hline Good & $70<$ IQA $\leq 90$ \\
\hline Average & $50<$ IQA $\leq 70$ \\
\hline Bad & $25<$ IQA $\leq 50$ \\
\hline Very Bad & $0<$ IQA $\leq 25$ \\
\hline
\end{tabular}

Fonte: Yisa et al. (2012). 


\section{RESULTS AND DISCUSSION}

The results of the physical, chemical and bacteriological parameters of the surface waters of the São João River were used in the calculation of the IQA for the months of August 2017 to September 2018. The classification of the water quality of the São João River was performed according to the values recommended by the National Sanitation Foundation.

The IQA-NSF behavior presented a variation of 60.75 to 76.19 during the study period, as shown in Figure 2. The study demonstrated that according to the IQA values, the water quality of the river basin may be categorized as average for most of the period. The study showed that $64.29 \%$ can be classified in the 'average' category and $35.71 \%$ can be classified in the 'good' category.

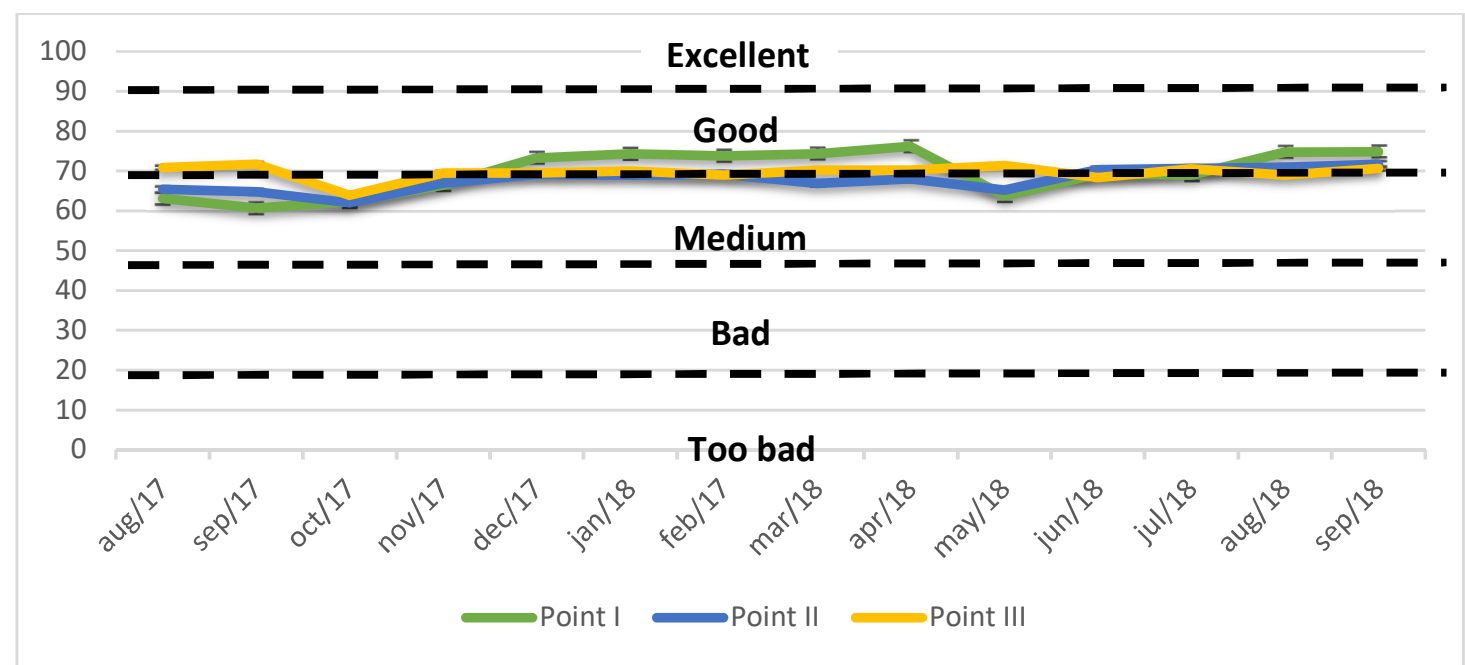

Figure 2: Representation of the topography of the public supply reservoir located in Ribeirão São João, municipality of Porto Nacional/Tocantins State.

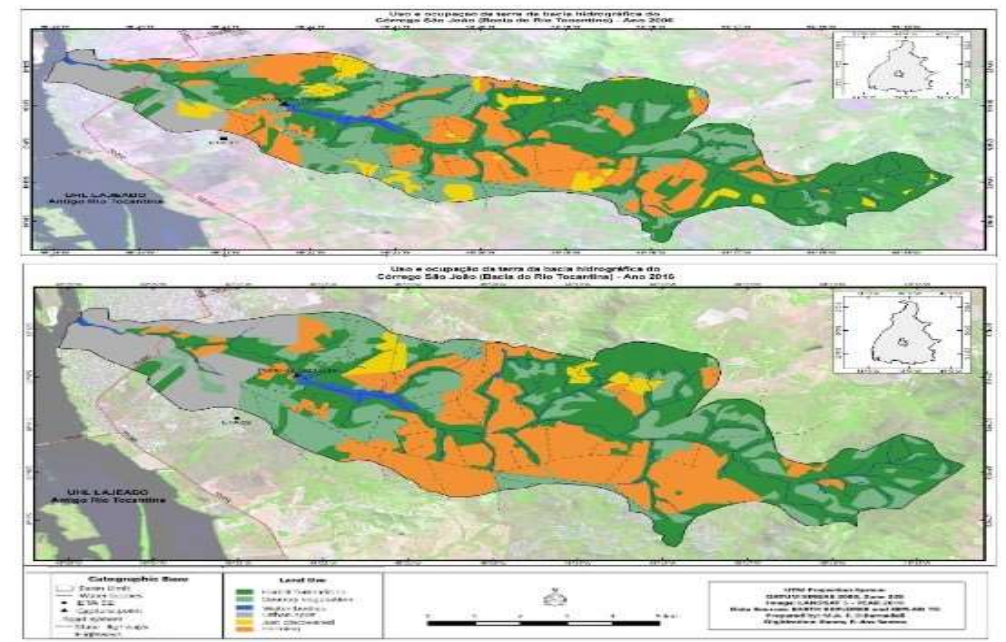

Figure 3: Soil use and occupation in 2006, 2011 and 2016 in the river basin of São João River Source: Bernadelli (2017).

The factor that strongly influenced this behavior was the use of the soil due to the agricultural and urban expansion, as explained by Bernadelli (2017) in Figure 3, which shows the use and occupation of the soil, where two study points are in the rural area and one point is in transition, urban and rural, which is located in water dam for urban supply. A study performed by Carvalho et al. (2016), the IQA in the rural area 
of the same hydrographic basin under study was classified as 'good', which shows after the intense agricultural activities that the quality of this water is diminishing in level. In the urban area, the author categorized the water from average to bad in rainy and dry seasons, where he stated that in areas where urban activities predominate, they were responsible for low quality levels.

\section{Temperature}

The temperature is categorized as one of the most important parameters, as it directly affects the physical and chemical processes performed in the body of water. In the study period, the average temperature was $25.6^{\circ} \mathrm{C}$, and the point that maintained the highest temperature was point three (PIII) with $30.4^{\circ} \mathrm{C}$ and the minimum temperature was $23.3^{\circ} \mathrm{C}$ at point one $(\mathrm{PI})$, showing an amplitude of $7.1^{\circ} \mathrm{C}$, according to Figure 4 . The lower temperatures at point one, located at the source of the basin, may be related to the preservation of the riparian forest in which there is an expressive presence of the vegetation.

In the dry season, it was observed that the water temperature was high in relation to the rainy season, due to the high temperature, and, consequently, to the low water level in the basin. Carvalho (1997), Dourados (2008), Balduino (2013), Pugas (2016) and Carvalho (2016) in similar studies found variations between $21.3^{\circ} \mathrm{C}$ and $32.4^{\circ} \mathrm{C}$, which showed that the results obtained in this study are within the common range of the study area.

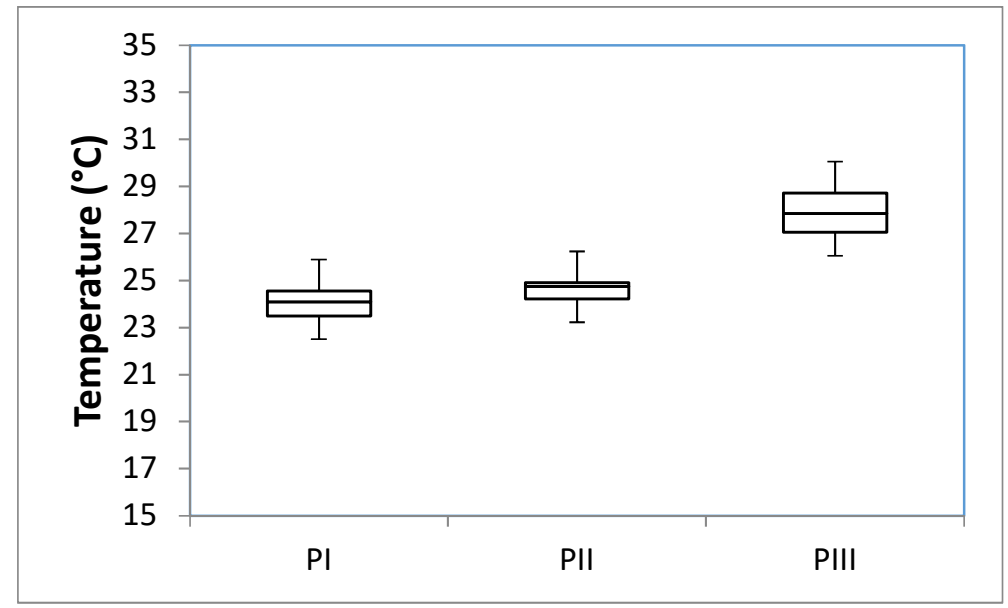

Figure 4: Water temperature in the São João River on the period of August 2017 to September 2018.

\section{Hydrogen Potential}

In relation to the $\mathrm{pH}$, the values ranged from 5.89 to 6.69 , with the minimum being recorded in September 2017 in the PI and the maximum also in the same month in the PIII. Ecosystems that have low pH values have high concentrations of dissolved organic acids of allochthonous and autochthonous origin. In these ecosystems, high concentrations of sulfuric, nitric, oxalic, acetic, as well as carbonic acid (VASCONCELOS et al., 2011).

Rivers that cross through wetlands also have waters with a very low $\mathrm{pH}$, due to the presence of decaying organic matter. Mangrove rivers are also included in this category (Maier, 1987). In Figure 5 it can be observed that the $\mathrm{pH}$ values were within the limit stipulated by CONAMA Resolution 357/2005 for class 
two, which fixes the $\mathrm{pH}$ range of 6 and 9 , but with values closer to the minimum limit of 6 , showing values slightly acidic, according to Derisio (1992) reference for $\mathrm{pH}$ values lower than 7.

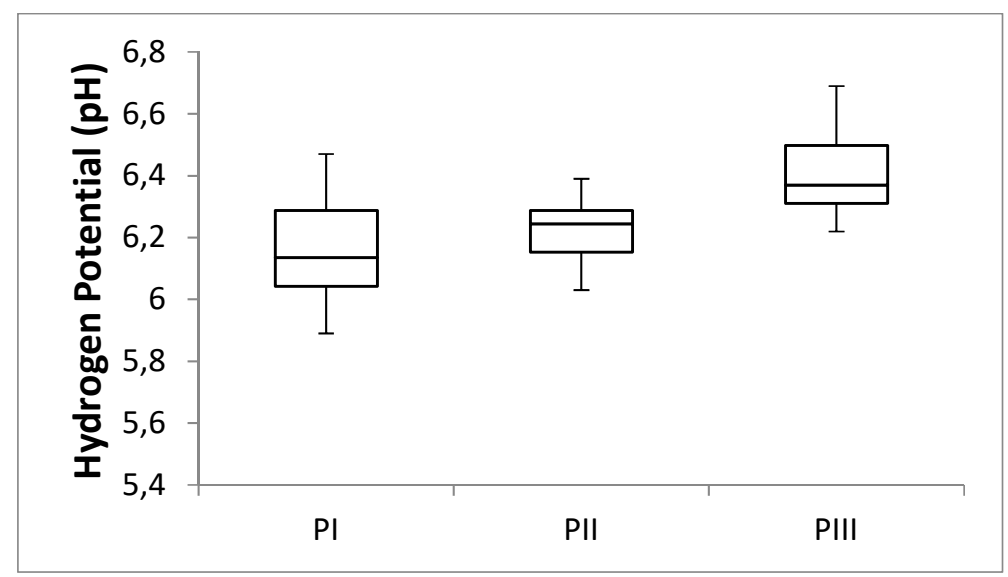

Figure 5: pH along the São João River from August/2017 to September/2018.

\section{Dissolved Oxygen}

Figure 6 shows the amount of dissolved oxygen in the water. The maximum value of $5.12 \mathrm{mg} \cdot \mathrm{L}^{-1}$ was obtained in August 2017 in the PIII and the minimum value of $3.87 \mathrm{mg} \cdot \mathrm{L}^{-1}$ occurred in October 2017 in the PI, with an average in the study period of $4,83 \mathrm{mg} \cdot \mathrm{L}^{-1}$ lower than the minimum value of $5 \mathrm{mg} \cdot \mathrm{L}^{-1}$ determined by the CONAMA Resolution $357 / 2005$ for class two. The obtained data show that in $52.4 \%$ of the analyzes the levels of dissolved oxygen were below the established resolution limit.

The low values obtained are characteristic of environments with high organic load, since decomposing organisms consume high concentrations of oxygen in the stabilization of the organic matter. For Esteves (2011), dissolved oxygen is one of the most important gases in the dynamics and characterization of aquatic ecosystems, having as main sources the atmosphere and photosynthesis. According to Oliveira et al. (2010), this photosynthetic action is only expressive after much bacterial activity occurs in the decomposition of organic matter, and also with the development of protozoa that, in addition to decomposers, also consume bacteria by clarifying the water and allowing the penetration of light.

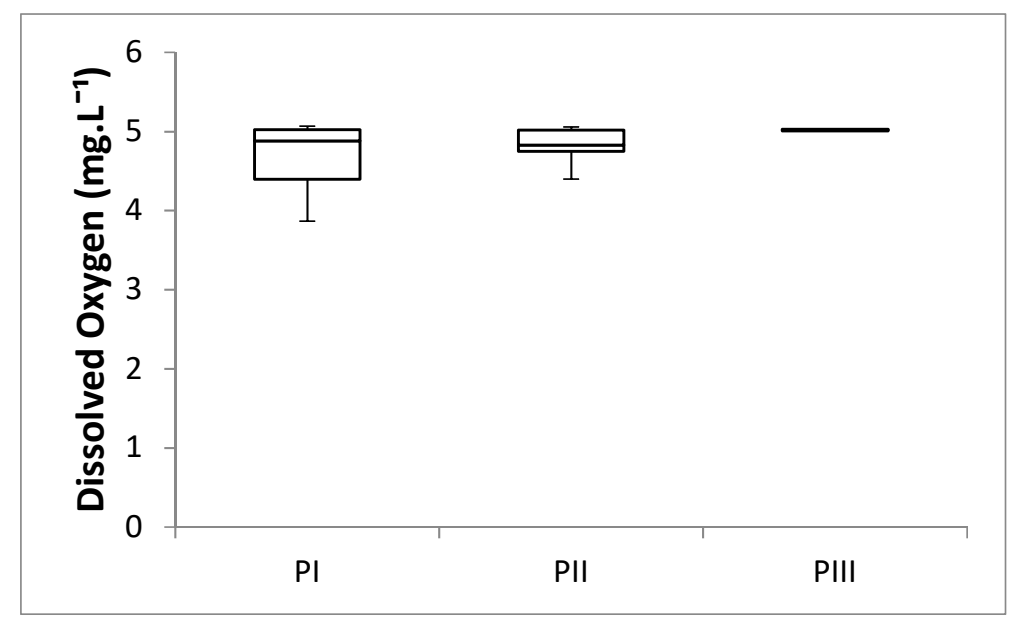

Figure 6: Dissolved Oxygen along the São João River from August 2017 to September 2018. 


\section{Total of Phosphorous}

Phosphorous is present in suspended solids solute solids, and in the nature it comes from the dissolution of soils and decomposition of organic matter, since its anthropic occurrence can result from the use of fertilizers, domestic and industrial dumps, detergents and animal excrements (DANELON et al., 2012). Figure 7 shows the concentration values of total phosphorus in the three points of São João river during the fourteen-month period. It was found that the highest value was of $0.14 \mathrm{mg} \cdot \mathrm{L}^{-1}$ in October and December 2017 in PIII and February 2018 in PII, and the lowest value was $0.01 \mathrm{mg} \cdot \mathrm{LL}^{-1}$ in the IP for the months of August and September 2017 and August and September 2018. The average of the study period was $0.05 \mathrm{mg} \cdot \mathrm{L}^{-1}$, exceeding the limit established by CONAMA Resolution 357/2005 which is $0.03 \mathrm{mg} \cdot \mathrm{L}^{-1}$ for class two lentic environments.

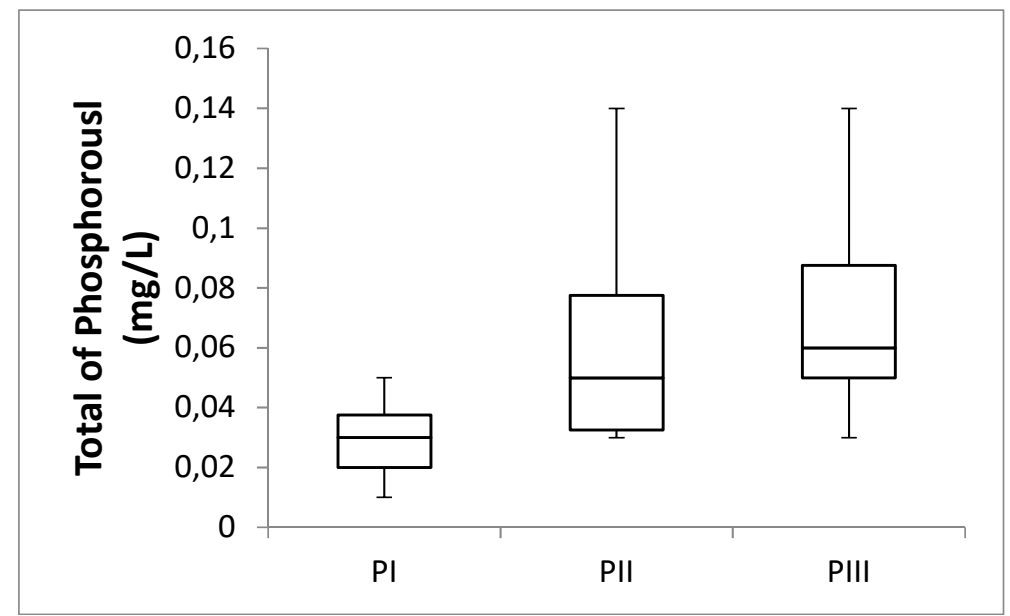

Figure 7: Total of Phosphorous along the São João River on the period of August 2017 to September 2018.

\section{Total of Nitrogen}

According to Esteves (2011), nitrogen is one of the most important elements in the metabolism of aquatic ecosystems, and this importance is mainly due to their participation in the formation of proteins, one of the basic components of biomass. Total nitrogen was present at high concentrations throughout the study period, with the average values observed being $4.77 \mathrm{mg} \cdot \mathrm{L}^{-1}$. Figure 8 shows the variations of the total nitrogen concentration obtained at the three collection points where it was verified that the lowest value was $3.12 \mathrm{mg} \cdot \mathrm{L}^{-1}$ obtained in the IIP in July 2018 and the highest was 6,715 mg . $\mathrm{L}^{-1}$ in the IP in August 2017. Marques (2011) in the Taquaruçu Grande creek in Palmas, evaluated the water quality and obtained values ranging from 2.09 to $7.53 \mathrm{mg} . \mathrm{L}^{-1}$, similar to those obtained in the present study.

The results obtained in this work do not meet the standards of the CONAMA Resolution 357/2005, for water of class two, with $\mathrm{pH}(\leq 7.5)$, since the values of total nitrogen cannot exceed $3.7 \mathrm{mg} \cdot \mathrm{L}^{-1}$. The high values of total nitrogen obtained during the study period reveal that the São João river is eutrophic, mainly due to the use of fertilizer agriculture, with sources like surface runoff, infiltration, decomposition of organic matter, agricultural residues, decomposition of organic matter and discharge of domestic sewage. According to Esteves (2011), to oxidize $1 \mathrm{mg}$ of the ammonium ion $\left(\mathrm{NH}_{3}\right)$ it is necessary 4,3 $\mathrm{mg}$ of oxygen, causing serious environmental implications, like high mortality values for fishes. 


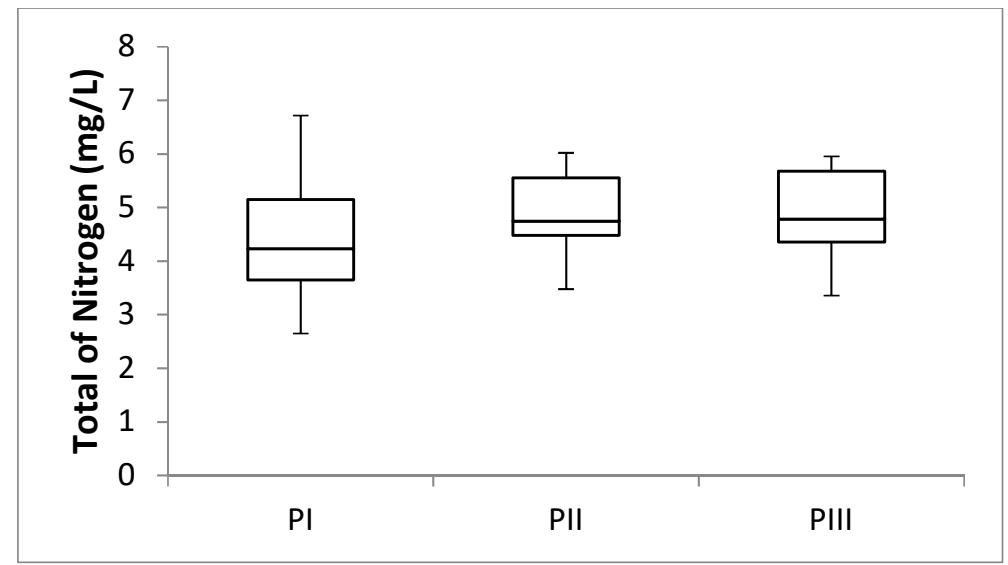

Figure 8: Total of Nitrogen along the São João River from August 2017 to September 2018.

\section{Biochemical Oxygen Demand}

According to CETESB (2009), "The DBO of the water is the amount of oxygen necessary to oxidize the organic matter by aerobic microbial decomposition to a stable inorganic form". The index allowed by CONAMA Resolution 357/2005 for this parameter, class two water, should be less than $5 \mathrm{mg} \cdot \mathrm{L}^{-1}$. The biochemical oxygen demand concentration of the analyzed water ranged from 1.39 to $3.04 \mathrm{mg} / \mathrm{L}$, with an average of $2.06 \mathrm{mg} / \mathrm{L}$ in the study period. As can be seen in Figure 9, during the study period all DOB values have always been below $5 \mathrm{mg} / \mathrm{l}$, which is the maximum value established for class two rivers, according to the CONAMA Resolution $357 / 2005$, something that points to the fact that there is no evidence of pollution by biodegradable organic matter for the basin under study, in which, according to this resolution, the waters are considered clean and proper to ecological preservation.

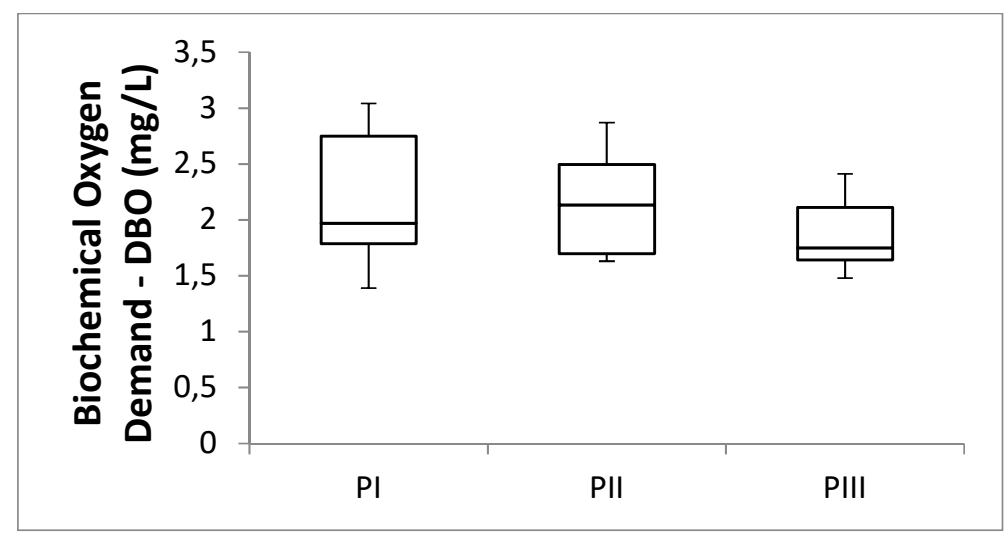

Figure 9: Biochemical Oxygen Demand along the São João River from August/ 2017 to September/2018.

\section{Turbidity}

The quality standard for class two river waters, established by the CONAMA Resolution $357 / 2005$, is of a turbidity level lower than 100 NTU (Turbidity Units). The turbidity of water is related to the amount of dissolved organic matter and suspended solids, which vary in size, from colloids to larger particles, which are deposited with a size larger than $1 \mu \mathrm{m}$ (APHA, 2005). From a sanitary point of view, when elevated, it can aesthetically affect water bodies or even increase the treatment for various uses. 
The turbidity values (Figure 10) at the sampling points were below 100 NTU during the series under analysis indicating that there is no pollution, with a minimum value of 2.59 NTU for the IP in September 2018 and a maximum value of 13,7 NTU for IIP in November 2017, with an average of approximately 9.5 NTU in the period under study, and the highest values occurred in the rainy season, which probably occurred due to the transport of solids to the riverbed, and, according to Sperling (2005), if this solid is of a natural origin it cannot bring direct inconveniences to water bodies, but can reduce the penetration of light, damaging the photosynthesis.

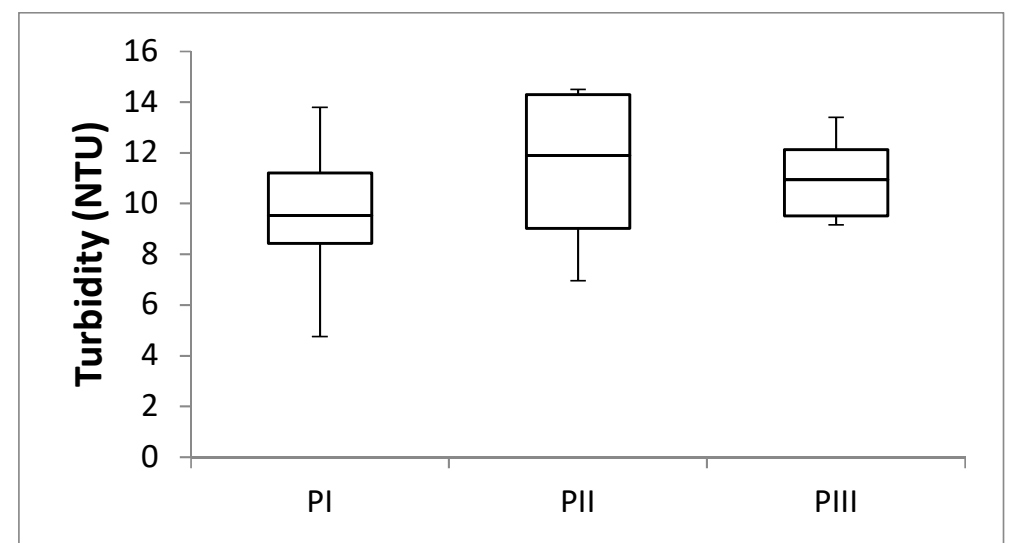

Figure 10: Turbidity along the São João River from August/2017 to September/2018.

\section{Thermotolerant Coliforms}

Fecal coliforms are a bacteria group present in the feces of humans and animals, and can be found in soil or in water bodies that can be detected though laboratorial examination, and when detected they make the water unfit for human consumption (GIRARDI, 2012). CONAMA Resolution 357/2005 states that for class two waters the value should be less than $1000 \mathrm{NMP} / 100 \mathrm{~mL}^{-1}$, while CONAMA Resolution 274/2000 referring to bathing this value should be less than $2000 \mathrm{NMP} / 100 \mathrm{~mL}^{-1}$.

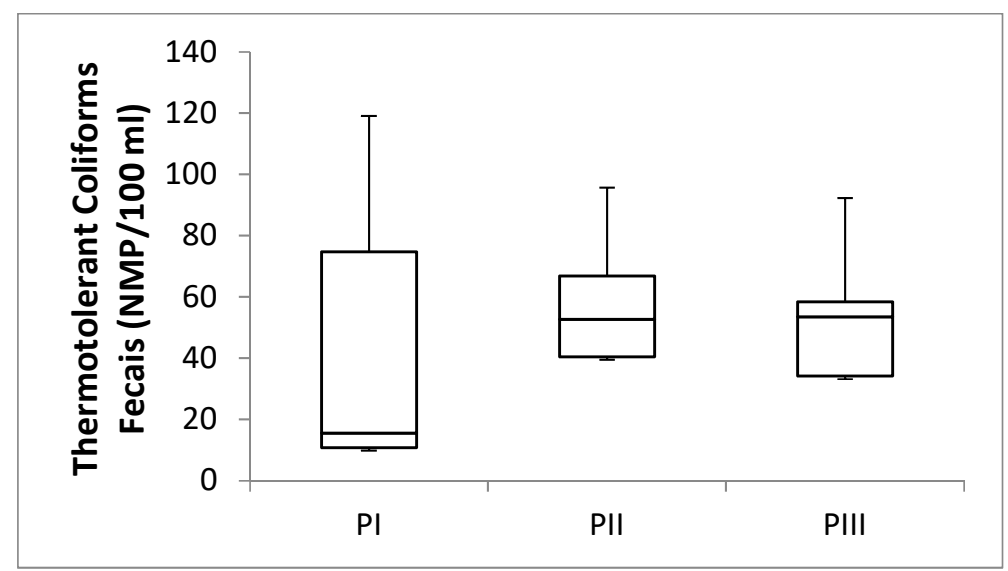

Figure 11: Fecal Coliforms along São João River from August/2017 to September/2018.

Fecal coliforms were practically present at all points in the analyzed series ranging from 6.5 to 119.1 $\mathrm{NMP} / 100 \mathrm{~mL}^{-1}$ for the PI, 23.7 to $95.7 \mathrm{NMP} / 100 \mathrm{~mL}^{-1}$ for the PII and 25.9 to $92,3 \mathrm{NMP} / 100 \mathrm{~mL}^{-1}$ in PIII, with mean values ranging from $45,47 \mathrm{NMP} / 100 \mathrm{~mL}^{-1}$ in the rainy season and $50.96 \mathrm{NMP} / 100 \mathrm{~mL}^{-1}$ in the period of drought in the three study points, according to Figure 11. The increase of coliforms in the points under 
study was possibly due to the contribution of feces from animals (cattle, chickens, etc.) and human feces along the banks of the basin, which carry out animal husbandry and private pits.

\section{Total Residues}

With the exception of dissolved gases, all water contaminants contribute to the solid loading. According to Resolution 357/2005 of the National Environmental Council (CONAMA), the maximum value allowed for Class Two waters is $500 \mathrm{mg} \cdot \mathrm{L}^{-1}$. The total waste can have as its main sources human wastes, sediments, vegetation, stones, among others, generated by the energy of the precipitation through the erosion and the transport by the flow (CARVALHO et al., 2016).

The total dissolved solids concentrations in the studied period ranged from $2.18 \mathrm{mg} \cdot \mathrm{L}^{-1}$ to $8.27 \mathrm{mg} \cdot \mathrm{L}^{-1}$, with an average for the study period of $6.22 \mathrm{mg}^{\mathrm{L}} \mathrm{L}^{-1}$ (Figure 12). As for class two waters, it was verified that this limit was not exceeded in the study period at all points, there being no restriction of the use of this water in relation to this parameter.

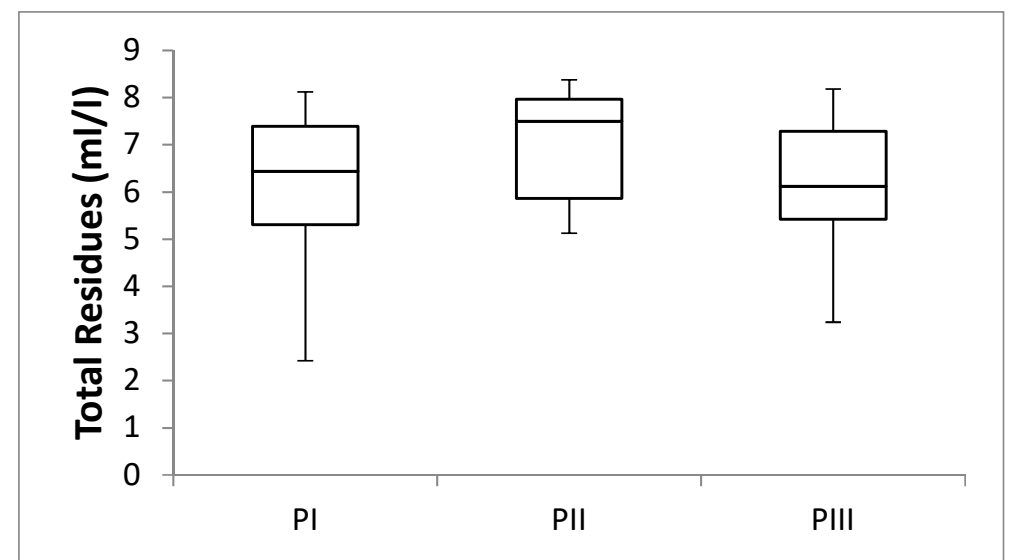

Figure 12: Total Residues along the São João River from August/2017 to September/2018.

\section{Glyphosate Agrochemical}

The detection of the pesticide was performed only in the PIII, where the water reservoir for public supply is located, in which the choice of the collection point of the bottom sediment, according to Balduino et al. (2018), it was determined after the bathymetric survey, according to the water flow and where there is the highest retention in the reservoir, since it will have a greater accumulation of sediment (Figure 13). Another important factor is the sediment characterization, because the clay soil has a greater capacity of retention by the the glyphosate agrochemical, which, in the author's study, the sediment was characterized as clay-silt, being $51.5 \%$ clay and $41 \%$ silt.

CONAMA Resolution 357/2005 states that for Class Two waters the value should be less than $65 \mu \mathrm{g}$ L, and for the Ministry of Health (BRAZIL, 2012), it states that the limit amount is $500 \mu \mathrm{g} / \mathrm{L}$, however the international parameters such as the United States protection Agency (USEPA) defines the limit of $700 \mu \mathrm{g} / \mathrm{L}$ as the maximum value of the substance in drinking water. In the European Union (EEC, 1980), the established 
value is $0,1 \mu \mathrm{g} / \mathrm{L}$ for any pesticide. The concentrations of glyphosate agrochemical for the period under study ranged from 0.02 to $0.09 \mu \mathrm{g} / \mathrm{L}$, with an average of approximately $0.05 \mu \mathrm{g} / \mathrm{L}$, according to Figure 14 .

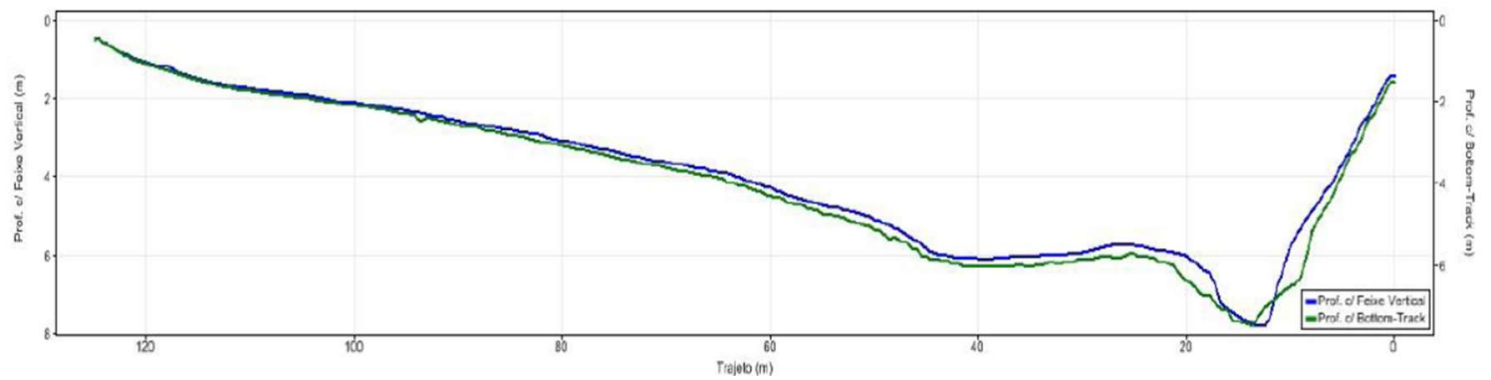

Figure 13: Representation of the topography of the public supply reservoir located in São João River, municipality of Porto Nacional/Tocantins.

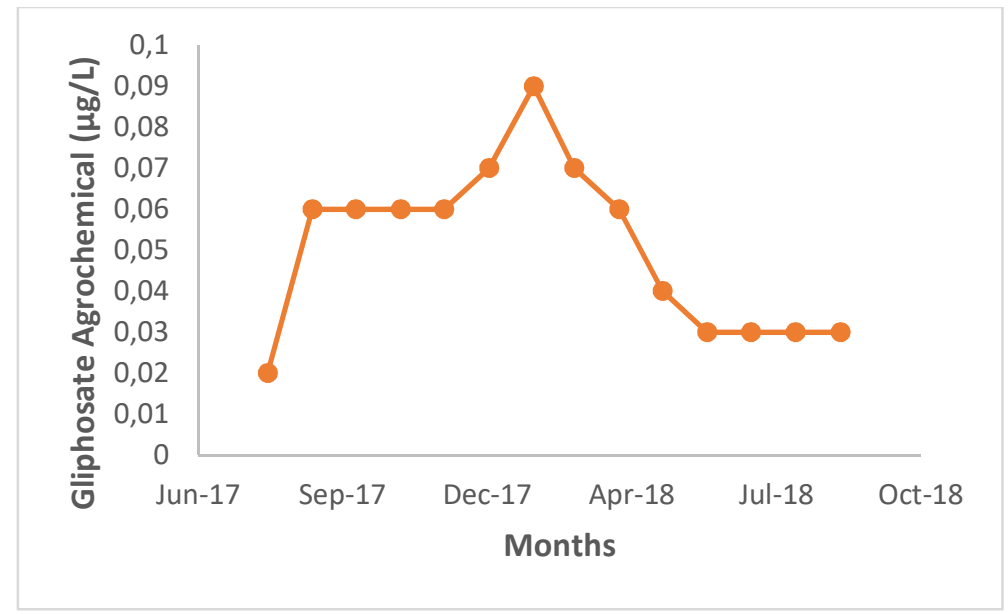

Figure 14: Concentration of agrochemical glyphosate in the water catchment reservoir for urban supply in São João River, municipality of Porto Nacional/TO.

In the dry season, the average concentration found in the study period was of $0.035 \mu \mathrm{g} / \mathrm{L}$, while in the rainy season the average concentration was of $0.067 \mu \mathrm{g} / \mathrm{L}$. Queiroz et al. (2011) states that the substance is present about 60 days after its dispersion in surface waters, where the herbicide can be adsorbed on the sediment and is therefore a long term contamination factor. In addition, sediments are considered as the final reservoir of many classes of contaminants derived from human activity in the environment. It is this ability to accumulate contaminants that are worrying the researchers, precisely because the pesticides are retained in the sediment layer, such as glyphosate, compromising the water quality due to its specific weight (POSSAVATZ et al., 2014).

Although ANVISA classifies glyphosate with low toxicity, there are negative effects for human health regarding the association of the formulations with the respective herbicide. Caldas et al. (2000) reported that in the United States, it is estimated that $35 \%$ of all cancer in the population in the northern region originates in the diet, the main factor being the pesticides present in food. According to Korbes et al. (2010), chronic exposure to agrochemical glyphosate may develop symptoms of depression, cancer, teratogenic effects, reproductive toxicity and late peripheral neuropathy.

A case study reported the development of Parkinsonism in a 44-year-old woman exposed for three years to glyphosate in the time she worked in a factory in China. Another case reported the development of 
Parkinsonism in a man of 52 years after having accidentally spilled on his body glyphosate herbicide (COSTA et al., 2003). Studies with umbilical, placental and embryonic human cell lines showed that five formulations of the Roundup ${ }^{\circledR}$ brand herbicide present in the European market were able to induce necrosis and apoptosis due to changes in cell permeability. The authors demonstrated the amplification of the cellular toxicity induced by glyphosate due to the presence of adjuvants in these formulations, which enabled the entry of the active principle into the cells, concluding that they are not inert (BENACHOUR et al., 2009).

The consequence of the use of agrochemical glyphosate, as well as its mixtures and damages to human health, mainly the insertion and excessive amount in the environment, its toxicity and accumulation in the supply reservoir only increases the concern with the population of the municipality of Porto Nacional. According to Rego et al., it is estimated that 25 to $33 \%$ of the global disease burden can be attributed to environmental risk factors.

\section{CONCLUSIONS}

The analysis of water quality was extremely important because it was able to detect oscillations in the IQA values at the three sampling points, where this factor is due to the dynamics of the use and occupation of the soil, and consequently, the water of each sampling point. Such a factor indicates that the IQA can be a tool for monitoring water quality and establishing trends, as well as clearly communicating to managers and the population about the quality of a river basin.

The results obtained during the study period, with respect to degradation, allowed us to perform a good analysis of the temporal space, which concluded that the waters of São João River did not meet all quality parameters determined by CONAMA Resolution 357/2005 for waters of class two. The NSF IQA calculation of the nine parameters (dissolved oxygen, biochemical oxygen demand, $\mathrm{pH}$, total nitrogen, total phosphorus, turbidity, total coliforms and total dissolved solids), four ( $\mathrm{pH}$, dissolved oxygen, total nitrogen and total phosphorus) disagreed.

In the municipality of Porto Nacional, it was verified that the urban supply represents the highest water demand, followed in order of consumption, irrigation, animal and industrial watering. The results obtained with regard to the detection of glyphosate agrochemical did not present values higher than the limit allowed by CONAMA Resolution 357/2005. These results inform us that in the dry season, from April to September 2018, the values ranged from 0.03 to $0.04 \mu \mathrm{g} / \mathrm{L}$, very different from April of the previous year, which was $0.01 \mu \mathrm{g} / \mathrm{L}$, and in the rainy season, ranging from 0.06 to $0.09 \mu \mathrm{g} / \mathrm{L}$, that is, values close to the permissible limit of the European Union, thus indicating the long term accumulation.

The data show that the oscillations of the parameters that were in disagreement were absorbed by others, a situation that could lead to unrealistic diagnoses of the conditions of the aquatic environment. Therefore, the use of the IQA (Water Quality Index) proposed by the NSF does not describe satisfactorily, as well as the limits allowed by the Brazilian legislation for glyphosate agrochemical, therefore, the results indicate that preventive and preservation measures should be adopted in the management of the water 
resources of this basin, avoiding that in a short time the IQA, currently classified as 'regular', is not classified in another class of inferior quality.

\section{REFERENCES}

APHA. American Public Health Association. Standard methods for the examination of water and wastewater. 19 ed. Washington: APHA, 2005.

BALDUÍNO, A. R.. Water quality of the São João river basin in the central-northern region of Brazil in the municipality of Porto Nacional/Tocantins. Dissertation (Master in Environmental Sciences) University of Taubaté, Taubaté, 2013.

BALDUINO, A. R.; SANTOS, M. G.; SOUZA, L. B.; LIMA, D. P.; CARVALHO, A. P.. Hydric balance and climatic classification of the city of Porto Nacional, state of Tocantins, inserted. The Legal Amazon, v.5, n.3, 2018.

BENACHOUR, N.; SÉRALINI, G. E.. Glyphosate Formulations Toxicity in Human Cells. Chem. Res. Toxicol, v.22, n.1, p.97105, 2009.

BOHNER, T. O. L.. The Environmental Impact of the Use of Agrochemicals on the Environment and in the Health of Rural Workers. 2011.

BRAZIL. Ministry of Health. 2914/2012. Ministry of Health, Secretary of Health Surveillance, General Coordination of Surveillance in Environmental Health. Brasilia: Ministry of Health, 2012.

BRAZILIAN ASSOCIATION OF TECHNICAL STANDARDS. NBR 9897: Planning of sampling of liquid effluents and receiving bodies. Rio de Janeiro, 1987.

CONAMA. National Council For The Environment. Resolution n.357: Provides for the classification of water bodies and environmental guidelines for their classification, as well as establishing the conditions and standards for effluent discharge, and other measures. 2005.

CALDAS, E. D.; SOUZA, L. C.. Chronical risk assessment of ingestion of pesticide residues in the Brazilian diet. Public Health Journal, São Paulo, v.34, n.5, p.529-537, 2000.

CARNEIRO, F. F.; PIGNATI, W.; RIGOTTO, R. M.; FRIEDRICH, K.; BÚRIGO, A. C.. Abrasco Dossier: An alert on the impacts of pesticides on health. São Paulo: Popular Expression, 2015.

CARVALHO, A. P.; BALDUINO, A. R.; MACIEL, G. F.; PICANÇO, A. $P$.. Pollution evaluation in rivers using water quality indexes: A case study in Ribeirão São João in Porto Nacional/TO. 2016.

CARVALHO, A. P.. Diagnosis of the influence of different uses (soil and water) on the water quality of Lajeando River. Monography (Bachelor in Environmental Engineering) University of Tocantins Foundation. 1997.

CETESB. Environmental Company of the State of São Paulo. Quality of Inland Water in the State of São Paulo, Environmental and Health Significance of Water and
Sediment Quality Variables and Analytical and Sampling Methodologies. 2009.

COSTA, M. D. L.; GONÇALVES, L. R.; BARBOSA, E. R.; BACHESCHI, L. A.. Neuroimaging Changes in Parkinsonism: A Five-Case Study. Arq. Neuro-Psiquiatr, São Paulo, v.61, n.2B, 2003.

DANELON, J. R. B.; NETTO, F. M. L.; RODRIGUES, S. C.. Analysis of the level of total phosphorus, ammoniacal nitrogen and chlorides in the waters of the terra branca river stream in the municipality of Uberlândia (MG). Geonorte, Uberlândia, v.1, n.4, p.412-421, 2012.

DERÍSIO, J. C.. Introduction to the control of environmental pollution. São Paulo: CETESB, 1992.

DOURADO, J. C.. Analysis of the São João River Basin, Tocantins: a methodological contribution to environmental planning and management. Thesis (Doctorate in Geography) - Federal University of Rio de Janeiro, 2008.

ESTEVES, F. A.. Fundamentals of limnology. Rio de Janeiro: Interciência, 2011.

GIRARDI, A. P.. Evaluation of the bacteriological quality of water in educational institutions of the municipality of São Miguel do OESTE/SC. Thesis (Doctorate Environmental Management) - Western Santa Catarina University, São Miguel do Oeste, 2012.

JACOBI, P. R.. Hydric Crisis, Water Scarcity and Human Rights: Environment \& Society opens call for papers for special volume. Scielo in Human Perspectives. São Paulo, 2015.

KORBES, D.; SILVEIRA, A. F.; HYPPOLITO, M. A.; MUNARO, G.. Changes in the Vesticulococlear System Due to Agrochemical Exposure. Literature Review. See. Brazilian Society of Phonoaudiology, v.15, n.1, p.146-152, 2010.

MAIER, M. H.. Ecology of the Jacaré river basin-Pepira. Water quality of the Main River. Science and Culture, v.39, n.2, p.164-185, 1987.

MARQUES, A. K.. Evaluation of the water quality of the Taquaruçu Grande River sub-basin and the area of influence in the reservoir of Luis Eduardo Magalhães Hydroelectric Plant/TO. Thesis (Doctorate in Sciences in the area of Nuclear Technology) - University of São Paulo, 2011.

MUDIAM, M. K. R.; PATHAK, S. P.; GOPAL, K.; MURTHY R. C. Studies on urban drinking water quality in a tropical zone. Environmental Monitoring and Assessment, v.184, p.461469, 2012.

OLIVEIRA, G. H.; PINTO, A. L.; PEREIRA, G. A.. Evaluation of the efficiency of the use of dissolved oxygen as the main indicator of surface water quality at the basin of the bom 
jardim river stream, Brasilândia/MS. GEOMAE Magazine: Geography, Environment and Education, Campo Mourão, v.1, n.1, 2010.

OLIVEIRA, M. G. N.; FRANÇA, W. B.. Analysis and Evaluation of the São João river basin for distribution. Monography (Bachelor in Civil Engineering) - President Antonio Carlos Tocantinense Institute, Porto Nacional, 2014.

POSSAVATZ, J. et al. Pesticides residues in bottom sediments in the hydrographic basin of the cuiabá river, mato grosso, brazil. Rev. Ambient. Água, Cuiabá, v.9, n.1, p.83-96, 2014.

PUGAS, A. B.. Evaluation of the Water quality of the São João river basin in the municipality of Porto Nacional/Tocantins. Monograph (Bachelor of Civil Engineering) - President Antonio Carlos Tocantinense Institute, National Harbor, 2016.
QUEIROZ, G. M. P.; SILVA, M. R.; BIANCO, R. J. F.; PINHEIRO, A.; KAUFMANN, V.. Transport of glyphosate by surface runoff and by leaching in an agricultural soil. New Chem., São Paulo, v.34, n.2, 2011.

SPERLING, M.. Introduction to water quality and sewage treatment. 3 Ed. Belo Horizonte: UFMG, 2005.

VASCONCELOS, V. M. M.; SOUZA, C. F.. Characterization of water quality parameters of the Utinga spring waters, Belém, PA, Brazil. Ambi-Water, Taubaté, v.6, n.2, p.305-324, 2011.

YISA, J.; JIMOH, T. O.; OYIBO, O. M.. Underground Water Assessment using Water Quality Index. Leonardo Journal of Sciences, p.33-42, 2012.

A CBPC - Companhia Brasileira de Produção Científica (CNPJ: 11.221.422/0001-03) detém os direitos materiais desta publicação. Os direitos referem-se à publicação do trabalho em qualquer parte do mundo, incluindo os direitos às renovações, expansões e disseminações da contribuição, bem como outros direitos subsidiários. Todos os trabalhos publicados eletronicamente poderão posteriormente ser publicados em coletâneas impressas sob coordenação da Sustenere Publishing, da Companhia Brasileira de Produção Científica e seus parceiros autorizados. Os (as) autores (as) preservam os direitos autorais, mas não têm permissão para a publicação da contribuição em outro meio, impresso ou digital, em português ou em tradução. 